DOI: 10.30519/ahtr.630783

Advances in Hospitality and Tourism Research (AHTR)

2020

An International Journal of Akdeniz University Tourism Faculty

Vol. $8(1)$

ISSN: 2147-9100 (Print), 2148-7316 (Online)

76-99

Webpage: http://www.ahtrjournal.org/

\title{
BRINGING HERITAGE SITES TO LIFE FOR VISITORS: TOWARDS A CONCEPTUAL FRAMEWORK FOR IMMERSIVE EXPERIENCE
}

\author{
Evinc DOGAN ${ }^{1}$ \\ Tourism Guidance Department, Tourism Faculty, Akdeniz University, Turkey \\ ORCID: 0000-0003-4874-7341 \\ M. Hamdi KAN \\ Architecture \& Urban Planning Department, Serik Gülsün-Süleyman Süral Vocational \\ School, Akdeniz University, Turkey \\ ORCID: 0000-0001-7947-7140
}

\begin{abstract}
This article aims to explore the ways in which heritage sites can be brought to life for visitors through immersive experience, and attempts to build a conceptual framework. It is based on a multidisciplinary project carried out by scholars of different backgrounds, which means that it relied more on knowledge and expertise sharing, rather than statistical data, even though a further research on consumer behaviour is planned. In heritage sites, the tangible aspects enable first-hand experience with the phenomena, providing a strong sense of reality. On the other hand, intangible aspects, which can be felt and evoked through the medium of heritage, are equally important. The sense of place is generated by those feelings and the meaning as a product of interpretation obtained by first hand experiences as well as any kind of medium. Getting sense of place is based on physical features making the place special or unique, stories and memories abiding connection to the place, as well as the spirituality or spectral aspects also called as hauntings. The essence of heritage interpretation lies in bringing the meaning to the surface as a result of cultural interfaces and engagements with our environment. The conceptual framework is threefold tackling with phenomenological, narrative and semantic levels of exploration, storytelling and meaning making. This article helps to elucidate
\end{abstract}

\section{Article History}

Received 8 October 2019

Revised 18 January 2020

Accepted 4 February 2020

\section{Keywords}

immersive experience

heritage tourism

absent presence

sense of place

storytelling

meaning making

\footnotetext{
${ }^{1}$ Address correspondence to Evinc Dogan, Tourism Guidance Department, Tourism Faculty, Akdeniz University, Antalya, TURKEY. E-mail: evinc.dogan@gmail.com
} 
the nascent field of immersive heritage exploring the experience (physical vs. virtual), the narratives (content vs. context) and the meaning (interpretation vs. action). In doing so, it suggests the ways in which immersive heritage can build up meaningful relationships in understanding and valuing heritage sites while enriching our experience through the absent presence between the physical and imaginary worlds.

\section{INTRODUCTION}

Human communication, starting with a very simple oral dialogic character lately evolving to literal monologic texts to communicate to larger populations and following generations, is recently in one of its most revolutionary stages. Since the beginning of literacy around 6-7 thousand years ago, the main aim was to push and even crush the boundaries of space-time by communication. Recent developments of immersive technologies in last 30 years, make it more and more possible everyday. In the field of heritage, digitization and the ever-increasing use of immersive technologies introduced new conceptualizations. This paper defines the "immersive heritage" by connoting applications of immersive technologies at heritage sites directed towards enriching visitor experience.

Though everyday life has always been a practice of dialogic communication based on oral conversations; one can easily observe a metronome-like change between the popularity of dialogic and monologic communication through the history of mankind. This was the case from the beginning. Even though primal human beings were communicating through their simple oral languages, after a while, they needed to create cave paintings in order to share knowledge between different tribes. Writing, was and still is the most popular method of sharing knowledge and storytelling. Printing technology, books, magazines and newspapers, followed by the invention of radios and televisions, marked the golden age of monologic communication methods. Even though the invention of telephone was a sign of re-emerging dialogic communication, especially radios and TVs surpassed any other method of communication for a long time. Popularity of those monologic methods might be a result of the hunger of common people to connect with specialists, scholars, artists and all kinds of previously unreachable people. This is followed by the raise of cell-phones and internet.

At the end of 20th century, a new and very advanced era of modern dialogic communication has begun. Cell-phones, at first, emerged from 
fictional Star-Trek universe and jumped directly into people's pockets. The ability to reach anyone, anywhere and anytime, made people addicted to talking and writing (texting) again. People began to spend more and more time to communicate with each other from long distances, rather than reading or watching third parties. This independence of communication from space, however, reduced the spatial existence of self. One can easily observe people actually being in the same location, communicating with distant individuals instead with each other. Gergen (2002, p. 227) describes this situation as "... at times our presence may go completely unacknowledged. We are present but simultaneously rendered absent; we have been erased by an absent presence." Internet, however made communication even more complicated.

Web is a place where everyone can create or consume any kind of data. One can dialogically communicate with someone else or can act like an authority that can produce monologic data sources. The latter created an environment of "dirty knowledge". In the first decade of internet use, people confused this open source knowledge sharing platform with edited and confirmed sources like books or "early" TV. They trusted the data available on the Internet and liked the idea to contribute in content creation; feeling like supposedly "unreachable" specialists, scholars, artists etc. of earlier times. People started sharing their so-called knowledge or creations with mass consumers, regardless of whether they are actually capable of this or not

Since Internet has become an untrustworthy environment, not only in the manner of professional knowledge or art sharing but also in the manner of personal life, it, again, created the hunger for real specialists and trusted content. The previous monologic communication methods evolved and adapted to newly emerged technologies such as e-books, audio guides, video tours and, at last, immersive storytelling and informative content created through multi-disciplinary projects carried out by specialists.

The question of the impact of new technologies on heritage, or heritigization, and heritage sites remains in the focus of the whole discussion about accessible, visitor-friendly and memorable immersive experience. Liritzis et al. (2015) examine increasing trend for digitization vs. traditional perceptions of the material culture. The line of reasoning is aimed at demonstrating visitors' behaviour whether they are active or passive agents who take part both in the production and consumption of the content. When viewed from the pragmatic side, virtual representation (virtual reality) contributes to knowledge and, in fact, makes it more 
accessible to anybody, anytime, anywhere. Yet, Liritzis et al. (2015, p. 315) posit that "in situ visit" is (relatively) advantageous in terms of "the idea of locality, the inner emotional kicking (co-movement) and unique stimuli, which are subjected to the five senses from the perception of ancient environment and objects," whereas "the dramatic deterioration of the environment and the broader landscape" observed in the real space "introduces misleading information of images where the visitor hardly ejects to hire those truly details of space-time". Immersive experiences, on the other hand, blur the line between the real and the virtual in the form of submersion applied to representation, while narratives become an instrument to capture the "feeling of presence in the represented reality" (Dominguez, 2017). According to Gerrig (1993, p. 2-3), the audience (visitor) becomes active in the process through two conditions, imagination and performing, as "a narrative serves to transport an experiencer away from the here and now [...] by the virtue of performing that narrative". Narratives play a crucial role in "contextualizing a particular content, thereby transforming it from facts or concepts to be memorized into useful tools" to address meanings (Barab et al., 2007, p. 61).

By tackling with the phenomenological, narrative and semantic levels of conceptual research, this article aims to explore the ways in which heritage sites can be brought to life for visitors through immersive experience. A short literature review of absent presence is given in the beginning, where absence and presence are defined as intertwined concepts drawing on the spatio-temporal qualities of heritage sites in connection to trace and memory. Then, the tripartite conceptual framework is presented and applied to the heritage context. The immersive experience is discussed by taking phenomenological approach and addressing sense of place, followed by description of the imaginary role of stories, myths and metaphors and, finally, construction of meaning is expressed through the process of heritage interpretation. The implication of the proposed framework is explained through the lessons learnt from major visitor sites based on Pittock's (2019) findings. Since immersive heritage is quite a recent topic, with a great potential for heritage sites, in the near future, hopefully, there will be more data collected for the use of immersive technologies and also for investigating how the visitors respond to such developments. The purpose of this study is to propose such framework and it will be further explained in the continuation. 


\section{THE MATTER OF ABSENT PRESENCE AND THE QUESTION OF DIGITAL RECONSTRUCTION}

This part presents the theoretical background by closely scrutinizing the poststructuralist theory "concerning the relationship between human beings, the world, and the practice of making and reproducing meanings" (Belsey, 2002). Drawing on Derridean notion of the concepts of memory and trace, language and signification is recognized as the foundation for a poststructural theory (Hurst, 2017). Traces of the past overwritten on the layers of meaning present new constructions. Memory and imagination play an important role for filling the traces with life (Meier et al., 2013). The notion of time can be understood as a continuous dialogue between past and present. At the intersection lies the absent presence, a concept most closely associated with Derrida (1994) in the poststructuralist theory.

Derrida coins the term "Hauntology" as a pun on the word "ontology" through the figure of a ghost - "specter" - rather "as a metaphor challenging dualisms being neither one thing, nor the other", neither present, nor absent (Davis, 2005, p. 373). Time and space merge in the hauntings of a bygone era or lost traces in the physical space. In Derrida's (1973, p. 65) point of view, the presence of the perceived present is "continuously compounded with a non-presence and non-perception". When put in the other way around, representational absence can be recognized as a form of presence. As a matter of speaking, the attempt should be looking beyond the duality of absence and presence as these two concepts are intertwined - "when we talk about presence we have a trace of absence in it" (Derrida, 1997). According to Derrida, "trace is the mark of the absence of a presence, an always already absent present" (Spivak, 1997, p. xvii). Thus, trace appears as the central concept in "Of Grammatology" (Derrida, 1997) in relation to Heideggerian approach towards "metaphysics of presence", and at the same time linked to what Levinas defined as "marked by the relation to other" and as "retaining the other as other in the same, as does retention" (Dastur, 2006, p. 49).

If we extend this framework by adding the notion of perception of time, we might talk about "the joint operation of perception and imagination" (Gregoric, 2007) by referring to "mneme" and "anamnesis" in Aristotle's "De memoria et reminiscentia" [On Memory and Reminescence, 350BCE]. Ricoeur (cited in Askin, 2009) makes a distinction here by qualifying mneme as cognitive - "memory as a kind of knowledge", and the anamnesis as pragmatic - "memory as praxis". When trace and memory are brought together around the temporal dimension in this framework, the 
cognitive aspect of mneme turns up to be read through representation concerning the relationship between absence and presence (Askin, 2009). While Aristotle argues about the memory, Plato's approach is rather inclined towards the trace through the relationship between representation (eikon) and imprint (tupos). Accordingly, in Platon's account trace is treated as "the representation of something absent", where memory becomes part of the "larger issue of imagination" (Hannoum, 2005, p. 124). Turning back to Aristotle, memory is appraised conjointly with time and imagination through "the sensation that produces affection and thus there is the presence of affection and the absence of the thing that produced the affection" (Hannoum, 2005, p. 124). In other words, even if the thing is absent, we have a memory of it through the affection. Askin (2009) emphasizes the temporal dimension for "distinguishing memory and imagination" characterized by absence based on the fact that "even though the traces are present, whatever caused them is not - not present meaning both not here and not now". The understanding of absence for Deleuze (1990, p. 256) is based on mediation - "to distinguish essence from appearance, intelligible from the sensible, idea from image, original from copy, and model from simulacrum".

In this framework, Virtual Reality (VR) creates the "presence", simultaneous with "the experience of "being" or "acting", when physically situated in another place" (Schwind et al., 2019). Fisher (2012, p.19) takes a critical perspective saying that it is both time and space that collapse in the age of tele-technologies, and the cyberspace as "events that are spatially distant become available to audience instantaneously". Consequently, new technologies disrupt conventional definitions of time and space, "no place like here and no time like now" (Atkin, 2006), based on the independence and availability leading to retention and repetition. Gallix (2011) gives the example of smartphones "encouraging us never to fully commit here and now, fostering a ghostly presence-absence", or YouTube as a "box of retrospective". Nevertheless, hauntings happen constantly "when a place is stained by time, or when a particular place becomes the site for an encounter with broken time" (Fisher, 2012, p. 19).

Desire to set one free from the boundaries of space-time existence through communication, is actually a matter of absent presence. "One is physically present, but is absorbed by a technologically mediated world of elsewhere" (Gergen, 2002, p. 227) and sometimes a world of a different time. Though this is more obvious, impressive and even dramatic with technological communication methods, writing and even oral story-telling 
sometimes create the same affect, mostly depending on consumers' imagination and the talent of the story-teller.

The dream of traveling back in time, and what one would expect from this kind of experience, is one of the most misunderstood concepts of history and archaeology. Especially considering the ancient era, this kind of misunderstanding is led by our "distorted lens" (Young, 2017, p. 37), which is a result of renaissance and neo-classical predecessors of our civilization. To escape from this distorted lens and produce knowledge and content independently, is one of the most difficult struggles of a specialist. Though producing information is relatively easier, creating realistically accurate immersive content for non-specialist consumers is much more difficult. This shouldn't be confused with the risk of inaccuracy of the content. As for the virtual environments that are created by multidisciplinary teams of specialized scholars, digital artists and software developers, there is no risk of inaccuracy. The content created by this kind of professional and academically capable people, would have no downs in the manner of academic data providing and/or education for that purpose. Also the ICOMOS Charter (2008) provides a clear guideline in this regard (ICOMOS Charter: 2.4). Though scholars are sharply divided into two groups concerning the truth value of narratives, where "...many hold that narratives have potential to bear truth", while others argue that "narratives do not reflect but construct reality" (Gergen, 1994, p. 188), history related disciplines are and have to be on the first side.

A modern observer runs the risk of bringing a distorted conception, or lens, to the experience of viewing ancient Greek and Roman public architecture, and this effect will only be magnified by an immersive experience. Modern observer, especially in Europe and New World, carries the enduring legacy of the revival movement of Classical architecture, which first gathered pace in Italy, and has now diffused throughout the world. In the Renaissance, the architecture of the Greeks and Romans was held up as a flawless ideal: the perfect manifestation of what a building should be (Wright, 1999, p. 1-9). A few prominent structures, such as the Parthenon in Athens, Pantheon in Rome and the Hagia Sofia in Istanbul, had remained largely intact and provided powerful inspiration to Renaissance architects. At the same time a large number of ruined monumental buildings were carefully studied and recorded, and their styles and ornamentation incorporated into public, private and religious buildings: these were innovative re-workings of old designs. These influential Renaissance buildings soon came to symbolise modern conceptions of power. This occurred again during the Neo-classical 
movement of the 18th and 19th centuries, when a great deal of public architecture took on the forms of Renaissance, Greek and Roman models (Cret, 1941, p. 8-9). This trend was not only popular in Europe, but also in the cities of the emerging powers of the New World (Young, 2017, p. 38).

When surrounded by these standing derivations of Greco-Roman buildings, the $21^{\text {st }}$ century observer will, consciously or unconsciously, attach meanings derived from one's own personal experiences, be they political, religious, educational or other. This effect might be called the "distorted lens". It seems that by digitally reconstructing ancient architecture, it is attempted to understand the effect that this architecture may had had on an ancient observer. If that is the case, it is to be questioned if the modern associations of Greco-Roman architecture might result in false conclusions. It might be wrongly assumed that an ancient observer made the same associations as the modern one does. Wright $(1999$, p. 5) points out changing subjective reactions of $18^{\text {th }}$ to $21^{\text {st }}$ century observers to ancient ruins: "... images, symbols and their meaning are culturally conditioned. They change, and sometimes in changing times they change quickly."

\section{TOWARDS A TRIPARTITE CONCEPTUAL FRAMEWORK}

The conceptual framework of the current study is threefold (see Fig. 1), tackling with phenomenological, narrative and semantic levels of exploration, storytelling and meaning making respectively. Each level is interrelated and complementary, drawing the whole framework in a cyclical way rather than following a linear process. Immersive heritage practice features key characteristics such as being "story-led, audience and participation centred, multimodal, multisensory and attuned to its environment" (Kidd, 2018). The interest for immersive experience in heritage context was carried forward by narrative turn, affective turn and ludic turn. The arguments raised by ludic turn is discussed through the phenomenological dimension through play and game with the aim of increasing level of engagement and getting sense of place. Storytelling is discussed within the context of narrative turn in relation to the content of the stories as the medium transmitting the voices and representations. How people feel, think, imagine and interpret is discussed in relation to meaning making as a matter of affective turn reflected on behaviour, within the complex pattern of personal, social and symbolic relationships. 


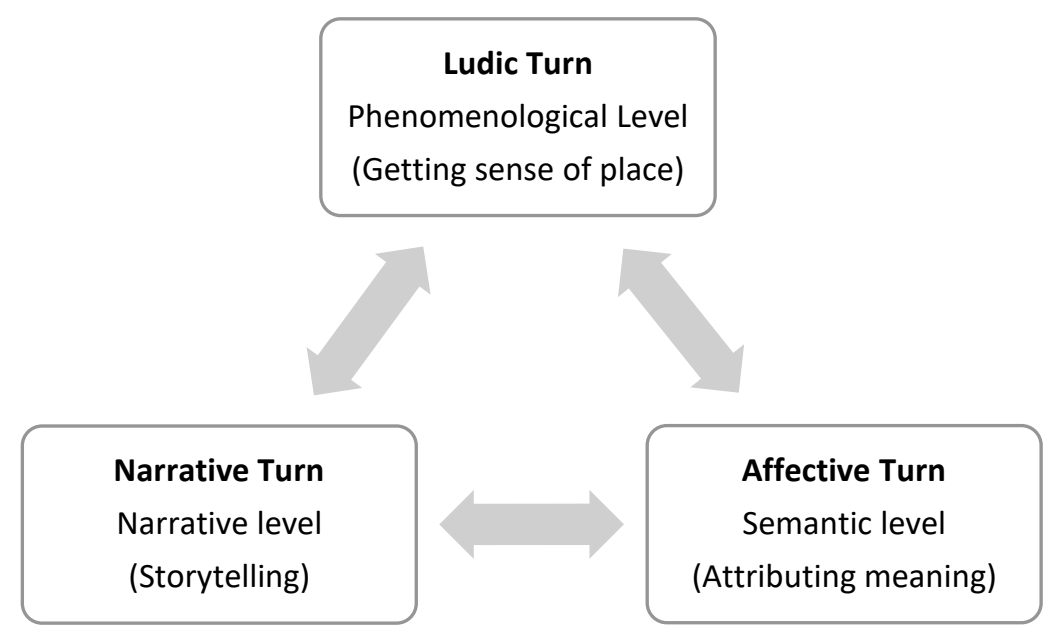

Figure 1. Conceptual Framework

\section{Getting Sense of Place}

Although, like most of the digital and computerized technologies, immersive tech was first developed for gaming purposes, there is a rising interest in using this tech for informative monologic communication. Virtual travelling in time and space is one of the most tempting opportunities that immersive tech provides. Using Virtual Reality (VR) to visit ancient sites as they were thousands of years ago, and doing this from one's own comfortable sitting room, is more than possible today. Or visiting a thousands of years old site and using Augmented Reality (AR) to watch it raise and resurrect in front of you, is equally possible and tempting. But, as Rahaman points out: "...the present trend of digital heritage is predominantly descriptive, technology-driven and imposing; rather than user-centric." (Rahaman, 2018, p. 215), so there are some points to be set, before one would eagerly put one of those high-tech glasses on.

The use of immersive technologies in heritage sites has its own ups and downs. Using this newly emerged tech for specialized consumers is highly profitable and useful as it lacks the accurate sense of a real "time travel" for unspecialized consumers, for now. But still VR and AR have the potential to overcome this struggle more than any recent method. The best results can be achieved by using VR and/or AR on-site. Avoiding the sense of unreality by actually being at the original location, sums up with the 
advantage of avoiding the misleading sense of being in the wrong spacetime relation.

Phenomenologists like Husserl (1913) and Merleau-Ponty (1945) address the critical role of physical space in human consciousness and meaning making by touching upon corporeality and bodily orientation. For Csordas (1993), embodiment is the starting point for analysing human cultural activity. Based on Merleau-Ponty's (1945) concept of "phenomenology of perception" and Bourdieu's $(1977,1984)$ notion of the body as "the locus of social practice", Csordas (1993) defines somatic mode of attention as "culturally elaborated ways of attending to and with one's body in surroundings that includes the embodied presence of others" (pp. 138-139). In the context of phenomenological archaeology, the encounter between the human and the artefact takes the form of somatic engagement and suggests the process of knowledge production - "knowledge of a past culture emerges from bodily engagement with the world in such a way that the material form, for instance, rocks and figurines, along with the intangible aspects of cultural heritage are enmeshed with human corporeality" (Flynn, 2008, p. 449). Dourish (2001, p. 126) argues that our engagement with the world and interaction with the artefacts and places make it meaningful based on three elements - (1) participative, (2) task accomplishing, and (3) practical action. In a world of physical and social reality, embodied interaction is at the intersection of "tangible interfaces" and "social computing", where embodiment stems from the user's sense of place and enjoyment (Dourish, 2001). This is closely linked to Ciolfi's (2015, p. 420) notion of human-centred computing in a setting where visitors become "active agents of interaction", embodied and situated; and where "body and senses, the physical environment, and the social world" construct a unified whole.

Accordingly, Rahaman and Tan (2009, p. 670) posit that built environment is a social product - "a mimesis of society's intentions and etiquette". Co-presence and shared experience are the conditions setting forth the participatory modes of interaction as a part of social dimension. In this manner, dialogic interaction also impacts on the way of attributing meaning affected by the co-presence.

\section{Storytelling}

The history of storytelling can be traced back to Plato's Republic and Aristotle's Poetics (Dubbelman, 2011) as discussed in the literature review 
of this paper by referring to the concepts of memory and representation. Todorov (1969, p. 10) coined the term "narratology" with the aim of presenting a logical and structural description of the way of storytelling. This follows the tradition of structuralism represented by Barthes, Greimas and Bakhtin with the aim of dissecting the narrative phenomenon into its parts and attempts to determine functions and relationships (Jahn, 2005). This paper draws closer to Barthes as it attempts to deal with "the semiotic presentation of a series of events semantically related in a temporal and causal way" where narrative is defined as a referential text with a temporal flow (Jaén \& Landa, 1996). In the context of place-based narratives, the term "to narrate" has a binding character for facts and fiction or past and present through myths, fantasies, images and communicating the meaning (Silver, 2005 cited in Fahmi, 2008, p. 41).

There are ancient narratives that are well-known from myths and historical records. Myths contain archetypal symbols, often themed as the figure of hero or the concept of heroization, creative acts and sacred origins (McAdams, 1993). In a wider cultural context, they are not only about chronicles of events, but also meanings shared and continually reconstructed in a subjective way. On the other hand, the genius loci, is what gives the place its unique character that can be felt on the phenomenological level. The narratives in the heritage context are sitespecific, accented on the unique qualities of a particular heritage site, which cannot be transferred onto another place (Farman, 2014). The myths tone up the emotions and remembrance by providing information weaved into narratives.

Bal (2009) conceptualizes narrative through a tripartite framework based on "text", "story" and "fabula". Fabula is related to the level of experiencing where performing occurs at a certain time and place. It is the story that draws semantic relationships and does it through the text, which could be in the forms of words, imagery or sound. The narration stimulates and/or shapes the interaction and thus connects to phenomenological level. This is also linked to praxis in Aristotle's terminology on the level of action and interaction through reconstructing the syntax of human behaviour which operates within narrative (Barthes \& Duisit, 1975, p. 252).

Regarding this several opportunities and different approaches, the future of storytelling in heritage sites is offering endless and unpredictable experiences for visitors. As long as it is planned and executed carefully, immersive tech is going to be able to make heritage sites as exciting as they are informative. 


\section{Attributing Meaning}

Historic places, sites and/or monuments are naturally part of the terminology incorporated with tangible aspects of heritage. Beyond the material heritage, "multiple processes of meaning making" occur in the way "visitors engage or disengage with these things, places and events" (Smith, 2012). Heritage interpretation is about linking tangible and intangible aspects as they coexist together facilitating imaginations based on "recollections and selections of (collective) memories" (Lehnes, 2016, p. 46).

Meaning is not discovered, as it is not dormant in the site waiting to be found by the subject. Meaning is constructed in different ways and it varies even with regard to the same phenomenon (Crotty, 1998). Experience, participation and stewardship offer paths to deeper meaning, which is central to heritage interpretation. In this framework, active involvement and participation is relevant in order to build meanings through individual experiences and interaction.

Fahmi (2008, p. 34) stresses the role of multimedia technologies for production and distribution of signs, where "representation, performance and exchange operate simultaneously". This draws close to Barthes' (1976) semiotic approach tackling the ways in which meaning is produced and represented in a system of signs. Rojek (1993, p. 136) designates tourist attractions (including heritage sites) as semiotic or textual meaning structures, where the "meaning is replaced by spectacle and sensation dominates value".

Bryman (1995, p. 176) links post modernism to tourist gaze and consumption attitude (Urry, 1990, p. 135) in the form of "post-tourism" brought by the "proliferation of images and signs presented as spectacles". In the context of post-tourism, tourist gaze is identified with "the systematic ways in which tourists are seeing, experiencing and consuming signs, symbols and places" (Lee, 2001). Yet, the performative turn posits active participation based on the "encounters with cultural signifiers" opening the floor to the cognitive understandings and emotional response rather than the exploitative nature of tourist imagery (Fahmi, 2008, p. 36).

Edensor (2012, p. 462) puts the emphasis on the absences "distributed in various materialities across space", and the narration is used to spur meaning. Memory is not a matter of retrieving but reshaping the meaning. Crang (2001, p. 201) argues about the "virtual multiplicity of possible futures and pasts" embedded in the ruins. The physical traces are 
not only signifiers of loss. Immersive experiences bring meaning to the surface by distorting and fragmenting both time and space. Hermeneutically, such experiences testify what is lost while reversing the order of movement from presence to absence as a matter of disappearance. Thus, virtual reality revokes absences rather than merely signifying past presences. Gordon (1997, p. 8) defines this feeling of reality, which spurs on momentary revelations, as a "transformative recognition". Our engagement with the absent presence offers alternative meanings to embellished heritage sites and conventional ways of restoring the past.

\section{IMPLICATION OF THE PROPOSED FRAMEWORK}

With the help of technology and digital worlds, there is a growing trend towards designing immersive experiences in the field of heritage. The conceptualization of heritage interpretation is often attributed to Tilden (1957) in search for the meaning. Although Tilden's model is still actively used and successfully implemented in heritage sites, it was not developed for virtual heritage. Rahaman's approach offers an up-to-date model for interpreting immersive experience at heritage sites based on four aspects first to satisfy the consumer's expectation, secondly provoking them for further conservation/protection of the heritage, third to promote learning of the past history and culture, and, finally, to present the past from multiple perspectives (2018, p. 211). Although there is no commonly agreed conceptual approach, Rahaman (2018) sets a very well-constructed and detailed framework supported by some experimental and statistical data.

Pittock (2019) explains some lessons learnt from the five major Scottish visitor sites (Bannockburn, the Burns Museum, Culloden, the Riverside and the National Library of Scotland). Accordingly, the implication of the proposed framework in this research is presented in line with the emerging areas addressed by Pittock (2019), shedding light on the tripartite conceptual framework to connect with visitors and bring heritage sites to life through immersive experience.

\section{Touching objects and sensing (Ludic)}

There is a need for handling objects, preferably physical object in the environment or virtual objects, which is "better than nothing" according to Pittock (2019). Various digital tools or media such as haptic devices are commonly used for embodied interaction and for accentuated human- 
machine interface. Similar to Gibson's (1986, cited in Rahaman, 2018) idea of tools "as the extension of our hands", Rahaman (2018) sees involvement and embodied action as the form of mediation, and digital heritage demands such interaction.

Feeling realistic sensations while moving and interacting in a virtual environment is crucial for the possibility of immersive experience (Brogni et al., 1999). In order to achieve this, visual input alone is not enough. Therefore, haptic interfaces are designed for rendering of the sensation of a physical interaction with the virtual environments. To give an example, PERCRO at Scuola Superiore S. Anna (Pisa, Italy) has developed force feedback systems to allow a natural mobility to human hand and arm by introducing the advantage of wearability and portability (Brogni et al., 1999). The study of PERCRO indicates some important facts about the use of such applications in heritage sites and visitor engagement:

An application on large scale can be a city guide on a wearable computer, that offer tourist as well as historical information to the user. The system could have an interface to consult the database, and he could be able to touch some virtual subjects with a haptic device: for example, for a sculpture positioned on the top of a church, it could be possible to have a reproduction in front of the user, looking that from any sides, feeling the surfaces or its weight. (Brogni et al., 1999, p.211)

The conceptual framework of this paper presumes that haptics is about touching and sensing, which reflects on the nature of the interaction and perception performed by ludic turn and state-of-the-art in serious game technology. Roma Nova is an example of immersive serious game built upon Rome Reborn, "a series of products for personal computers and VR headsets that make it possible to visit the now-vanished ancient city - think of it as the place where virtual tourism meets virtual time travel" (Rome Reborn, n.d.). Another example is Muru in Wonderland, which is aimed at creating a VR experience for children through a game of hide and seek for finding and grabbing or poking Muru (a virtual character). The setting for this game is composed of 360-degree real-world footage of places in Gwangju with realtime interaction through 3D video tour (Jang et al., 2016). The user interaction is enriched through storytelling as well as physical (haptic) contact (Machidon et al., 2018, p. 257). 


\section{Combining virtual and physical experiences with a strong storyline (Narrative)}

Contrary to the popular belief that more visual experiences would need less narrative, information is important for the users regardless of the mode of delivery (Pittock, 2019). Nevertheless, "narrow or limited narrative restricts the effectiveness of digital immersives" (Pittock, 2018, p. 224). Stories play a crucial role in this framework for organising and contextualising experiences and information (Interpret Europe, 2017). In conjunction with the temporality of memory and trace, the spatial organization of the material world is a medium for experiencing. If you are visiting the site and looking at the ruins, you are trying to find out "what was not there by capturing images of what was" (Goulding et al., 2018, p. 28). This can be either through images and illustrations or reconstructions. Representation, memory, and storytelling mediate the experience and the meaning. Bucher (2017) argues that storytelling for VR is "less about telling the viewer a story and more about letting the viewer discover the story", which recognizes the role of the viewer in meaning-making as an interactant and creative agent.

Young (2017) comments on the virtual reconstruction and its impact on shaping the experience:

Another smudge on the lens of the modern observer is that he or she is faced with an incomplete picture of the ancient cityscape. A plan of a city, a computer reconstruction, a visit to an ancient site - or a virtual reality experience - may succeed in communicating the broader impression of the monumental core of a city. Yet, however carefully researched the reconstruction may be, it falls short of providing a modern observer with the complete and authentic experience of walking through an ancient city. Then the modern observer must accept the incomplete nature of their impression of ancient monumental architecture. The details like the activity on the streets, the type of people who frequented them and the business they pursued, as well as the overall collective effect of the city-scape, with its hierarchy of buildings, temples crowning the skyline, colonnaded thoroughfares with balconies and dingy narrow side streets leading to crowded insulae, as well as the smells and the noises are alas far from the reach. (p. 40)

MacDonald (1986) gives an example for colonnaded thoroughfares;

[...] the photogenic files of columns one sees at many sites [...] are misleading with respect both to the original appearance of these elaborate thoroughfares and to their function as urban elements. Their walkway roofs are gone, and 
often their bordering buildings too, losses that the preservation of portions of entablatures cannot make good... The effects produced by these shaded corridors... have vanished forever. Even when the façades of the buildings have been preserved, the light is always wrong. (p. 43)

Immersive experiences become more meaningful through storytelling, which works for filling the voids and bringing past to life. According to Rose and Wylie (2006, p. 475) the spatio-temporal specific tensions between presence and absence shape our engagements with the environment and understanding of the material. Goulding et al. (2018, p. 25) argue about the notion of absence in themed heritage that is "concealing or rendering invisible, alternative, subaltern or excluded narratives to those of the master discourse". Meier et al. (2013, p. 424) view the absence as a relational phenomenon between the materiality and the immateriality, the social and the natural; so that "the relations give absence matter".

Emotional resonance and human connection are as important as knowledge. EMOTIVE project draws on the power of "emotive storytelling" with the aim of engaging visitors, triggering their emotions, connecting them to other users, and enhancing their understanding, imagination and experience (Perry et al., 2017). In order to achieve this aim, "a plot-based approach that resonates with people" is adopted through combining hybrid story spaces (online and on-site) and allowing multipleusers not only "interacting with the story" and also "collaborating to advance it" (Roussou et al., 2017, p. 408),

The site of the Ancient Agora in Athens is told by the "1001 stories of Ancient Agora" representing universal concepts such as life, death, love and struggle to provoke sympathy or empathy. According to Roussou et al. (2017), the responses of the users vary depending on their preferences and cognitive load caused when interacting with the application:

"The whole idea of walking around as someone's telling you not about what you are seeing, but a story, is very powerful." (p. 417)

"It's a narrative where you're free to look around and you have these punctuated moments where it mentions a building and you're, like, oh I'm here in the story!" (p. 417)

"I'd like to learn more about society in Antiquity, to feel the aura of being here in the times of Kimon, Perikles, Plato or Socrates. In fact, I would've liked Kimon to give me the tour." (p. 417) 
As it can be understood from the feedback of the users, narratives play an important role in visitor engagement. Yet, a powerful story becomes even more effective when supported by sensations. Another positive implication is that narratives are accessible before, during or after the visit. Nevertheless, perhaps the most important implication of the use of narratives in immersive heritage experience is the user-generated content. As Byrne (2019) argues "some stories speak to us more than others, which comes across in part from our likes, follows, views and shares" which is emphasized as the effect of the social media. This is not only about creating the content but also sharing it with others. Therefore, the engagement of heritage can be recognized as an interplay between narrative and meaning, thus between "the collective examination of the past and the visualization of an alternative future" (Vit-Suzan, 2016, p. 175).

\section{Preferences on reconstruction vs digital simulation (Semantic)}

The "hard architectures" of the present landscapes merge with the liquid "soft architectures" of digital media (Beckman, 1998). Sheller and Urry (2000) argue that "places do not disappear, but their logic and their meaning become absorbed in the network", which suggests co-presence and drawing flexible paths through space and time. Fahmi (2008, p. 33) addresses this phenomenon as the "heterotopias of mobile communications" functioning as signs rather than places. This form of "replicated co-presence" (Terkenli, 2002) through mobile technologies and virtual reorganization of space draws complex bodily, emotional and cognitive interrelationships between the subject and environment.

When Gillings (2000, p. 59) warned of the "relentless questing for the elusive grail of photorealism and ever more faithful simulation", he was commenting on a phenomenon that emerged along with the potential of photorealistic VR environments. And a passage written by Christopher Ratté (2001), describing how a visitor would have seen Aphrodisias in Late Antiquity, can be examined as an example:

The first sight to greet a visitor to Aphrodisias in late antiquity would have been the great cathedral, visible for miles from every direction... As he drew closer, the visitor would see the city wall, and the now-venerable cemeteries lining the major roads out of town. Entering any of the principal gates, he would have found himself looking down a broad, straight street toward one of the several monuments that marked the centre of town. As he walked down this street, he would catch occasional glimpses down cross-streets into 
residential neighbourhoods whose outward appearance had probably not changed significantly for centuries. If he had an antiquarian interest, he would linger by the remnants of pagan sanctuaries and other early buildings, now occupied by workshops or incorporated into private houses and so on and so on. (p. 138)

This passage is surely imaginative as it is also slightly troubling with this walk-through description of the city, and its tendency towards certain vagueness with the use of the term "visitor". Using terms such as "visitor" or "observer" is a common technique when discussing the effect of public buildings on ancient observers and the modern self is very reluctant to state the identity of these "visitors" or guess what they were thinking. Yet it must be accepted that identity is anything but non-specific and that as a reader, when confronted with such empty terms like "visitor" or "observer", the strongest urge is to place one's self, the "modern" observer onto that ancient streetscape and imagine how one would interpret its architecture (Young, 2017, p. 26-30).

If one could take an ancient observer and show them the digital reconstructions of ancient cities, it is reasonable to say that they would have a completely different experience. The first thing that might strike them is the haunting emptiness of modern restorations, and then the gross errors in the reconstructions. An ancient observer would also derive a more complex reading from the cityscape, one that is simply beyond us.

However, it is also true to say that the modern observer has come to expect digital reconstructions of ancient cityscapes to be empty, white and eerie. If one is represented with a more authentic picture, in other words, if one sees objects within the scene that they think should not be there, that may feel like something is not quite right. The suspension of disbelief is broken.

Apart from all these complications mostly in the manner of sense and perception, digital reconstructions of ancient cities and monumental architecture especially in immersive technological environments, has its own advantages in technical and professional use (Barcelo, 2009; Hopkins, 2016, p. xiiv-xiv; Wheatley \& Gillings, 2000, p. 2-5). One of the most important fields of interest for an architectural historian is to better understand the interrelationship of individual buildings within a city. Using immersive technologies to examine ancient cities is the best way to study this interrelationship from a previously unthinkable number of angles and positions, moving easily from position to position and at a human scale. Also, using photometry instead of 3D modelling would allow 
scholars to examine architectural remains of distant locations more easily and accurately, without actually travel around the world. And most importantly, the on-site ruins can be conserved rather than being permanently altered by onsite reconstructions, which cannot always be perfectly practiced.

As one of the most serious and accurate VR applications on heritage sites recently, Lithodomos VR and some content of the project can be evaluated as real-life examples (www.lithodomosvr.com/apps/). The free mobile application of the project, LVR Engage, has multiple different content such as Olympia, Athens (Greece), Ostia, Rome (Italy) and more. Even though there is no statistical data to make a comparison, two main approaches can be seen, each one having its own pros and cons. First is to erase people, their activities and relations, shortly "life" from the scene and present mere environmental atmosphere, with buildings, terrain, streets and all other lifeless elements that create the canvas for the real picture (as in examples of Greece and Rome). This would force the consumer to focus on the man-made features placed on a specific terrain, without any interruption of the man itself. This approach would face the visitor with the picture of a naked reality, but with absence of a story, may be encouraging one to imagine their own. As usual, the second approach is quite the opposite of the first: creating immersive content with the most possible accuracy, including people, the social atmosphere they interact, daily routines of a city and its different sections, and all the relations between all these factors; or even creating scenes of mythical and/or historical well known stories to surround the visitor (as in Ostia example). This second approach would definitely create a much more immersive experience and would be much more impressive. But it would create a lot of distraction from the artistic, structural and conceptional features of the environment, pulling the consumer in to a flood of interactions. Also this second approach would take away the freedom of imagination, forcing the visitor to live the experience that has already been set. Yet, it is hard to tell about visitor preferences because they are subjective and tied to expectations shaped by cognitive processes and cultural codes.

\section{CONCLUSION}

Heritage sites bear traces of the past and modes of representation which bring them to life through immersive experience. Flynn (2008, p. 447) points out interpretative digital heritage as an emerging area in terms of both theory and practice, which draws on "multi-vocal and culturally embedded 
interpretations of the past". The motive is bringing past to life through "the way people make sense of the world as social practice" (Flynn, 2008, p. 447). This introduces the necessity for drawing a complex framework based on visualisation, sensing, participating and cultural learning rather than merely taking linear narratives and representations into account.

Rahaman's (2018) approach suggests phenomenological models of perception and highlights the role of embodied experience for knowledge production rather than behaviourist models of learning determined by physical processes and knowledge transfer. Sense of place is intrinsic part of this model for the visitor in order to become part of the context and enjoy the immersive experience. The presence is affected by the co-presence capitalising on the social values and narratives, thus creating collective memory. In this way, reconstructions and simulations are perceived as social products, collective memory devices and manifestations of collective cognitive background (Rahaman, 2018), which helps to attribute meaning to a heritage site.

In sum, this article helps to elucidate the nascent field of immersive heritage experience by tackling with the sense of place (physical vs. virtual), the narratives (content vs. context) and the meaning (interpretation vs. action). The tripartite conceptual framework presented by this article suggests that immersive heritage experience lies "at the nexus of story, body and senses" (Kidd, 2018). In doing so, it presents the ways in which immersive heritage can build up meaningful relationships in understanding and valuing heritage sites while enriching our experience through the absent presence between the physical and imaginary worlds. This, in fact, provides a sensorial experience with heritage through the presence in the virtual environment and stimulates real life experience through shaping perceptions and attributing meaning for what is left behind and why it matters.

\section{ACKNOWLEDGEMENT}

This research is undertaken as a part of the project (NMGR1180505 - A Tale of Two Cities: Investigating the Use of Virtual Reality to Connect Consumers to Culture) funded by British Academy for Newton Mobility Grants 2018-19 RD1 (Newton Fund). 


\section{REFERENCES}

Askin, R. (2009). Mneme, anamnesis and mimesis: The function of narrative in Paul Ricoeur's theory of memory. FIAR: Forum for Inter-American Research, 2(1). Retrieved February 28, 2020, from http://interamerica.de/currentissue/askin/\#more-193

Atkin, A. (2006). There's no place like "here" and no time like "now". American Philosophical Quarterly, 43(3), 271-280.

Bal, M. (2009). Narratology: Introduction to the Theory of Narrative. Toronto: University of Toronto Press.

Barab, S. A., Sadler, T. D., Heiselt, C., Hickey, D., \& Zuiker, S. (2007). Relating narrative, inquiry, and inscriptions: Supporting consequential play. Journal of Science Education and Technology, 16(1), 59-82.

Barcelo, J. A. (2009). Computational Intelligence in Archaeology. New York: The IGI Group.

Barthes, R. (1976). The Pleasure of the Text (R. Milter, Trans.). New York: Hilland Wang.

Barthes, R., \& Duisit, L. (1975). An introduction to the structural analysis of narrative. New Literary History, 6(2), 237-272.

Beckmann, J. (Ed.) (1998). The Virtual Dimension: Architecture, Representation and Crash Culture (pp. 145-155). New York: Princeton Architectural Press.

Belsey, C. (2002). Poststructuralism: A Very Short Introduction. Oxford: Oxford University Press. doi: 10.1093/actrade/9780192801807.001.0001

Bourdieu, P. (1977) Outline of a Theory of Practice (R. Nice, Trans.). Cambridge: Cambridge University Press.

Bourdieu, P. (1984). Distinction (R. Nice, Trans.). Cambridge, Mass.: Harvard University Press.

Brogni, B., Avizzano, C., Evangelista, C., \& Bergamasco, M. (1999). Technological approach for cultural heritage: Augmented reality. In: RO-MAN '99: Proceedings of the 8th IEEE International Workshop on Robot and Human Interaction, pp. 206-212.

Bryman, A. (1995). Disney and His Worlds. London: Routledge.

Bucher, J. (2017). Storytelling for Virtual Reality: Methods and Principles. New York and Oxon: Routledge.

Byrne, W. (2019, August 6). What is digital storytelling and what has it got to do with cultural heritage?, Europeana Pro. Retrieved February 28, 2020, from https://pro.europeana.eu/post/what-is-digital-storytelling-and-what-has-it-got-todo-with-cultural-heritage

Ciolfi, L. (2015). Embodiment and Place Experience in Heritage Technology Design. In M. Henning (Ed.), The International Handbook of Museum Studies: Museum Media (pp. 419-446). Hoboken, NJ: Wiley.

Crang, M. (2001). Rhythms of the city: Temporalised space and motion. In N. Thrift \& J. May (Eds.), Timespace: geographies of temporality (pp. 187-207). London: Routledge.

Cret, P. P. (1941). The Ecol des Beux-Arts and architectural education. Journal of the American Society of Architectural Historians, 1(2), 3-15.

Crotty, M. (1998). The foundations of social research: Meaning and perspective in the research process. London: Sage.

Csordas, T. J. (1993). Somatic modes of attention. Cultural Anthropology, 8, 135-156. doi:10.1525/can.1993.8.2.02a00010

Dastur, F. (2006). Derrida and the question of presence. Research in Phenomenology, 36, 4562.

Davis, C. (2005). Hauntology, spectres and phantoms. French Studies, 59(3), 373-379. 
Deleuze, G. (1990). Plato and the Simulacrum. The Logic of Sense (M. Lester, Trans.). New York: Columbia University Press.

Derrida, J. (1973). Speech and Phenomena and Other Essays on Husserl's Theory of Signs (D. B. Allison, Trans.). Evanston: Nortwestern University Press.

Derrida, J. (1994). Specters of Marx (P. Kamuf, Trans.). New York and London: Routledge.

Derrida, J. (1997). Of Grammatology (G. C. Spivak, Trans.). Baltimore: Johns Hopkins University Press.

Domínguez, E. (2017). Going beyond the classic news narrative convention: The background to and challenges of immersion in journalism. Frontiers in Digital Humanities, 4(10). doi: 10.3389/fdigh.2017.00010.

Dourish, P. (2001). Where the Action Is: The Foundations of Embodied Interaction. Cambridge: MIT Press.

Dubbelman, T. (2011). Playing the hero: How games take the concept of storytelling from representation to presentation. Journal of Media Practice, 12(2), 157-172.

Edensor, T. (2012). Vital urban materiality and its multiple absences: The building stone of central Manchester. Cultural Geographies, 20(4), 447-465.

Fahmi, W. S. (2008). Glocal Heterotopias: Neo-. Flaneur's Narratives within transit spaces. In P.M. Burns \& M. Novelli (Eds.), Tourism and Mobilities: Local-Global Connection (pp. 33-64). Oxfordshire: CAB International Publishing.

Farman, J. (2014). Storytelling with mobile media: Exploring the intersection of sitespecificity, content, and materiality. In G. Goggin \& L. Hjorth (Eds.), The Routledge Companion to Mobile Media (pp. 528-537). New York and Oxon: Routledge.

Fisher, M. (2012). What is hauntology? Film Quarterly, 66(1), 16-24.

Flynn, B. (2008). Augmented visualisation: Designing experience for an interpretative cultural heritage. In 12th International Conference on Information Visualisation, pp. 447-452.

Gallix, A. (2011, June 17). Hauntology: A not so critical manifestation. The Guardian. Retrieved February 28, 2020, from https://www.theguardian.com/books/booksblog/2011/jun/17/hauntology-critical

Gergen, K. J. (1994). Realities and Relationships: Soundings in Social Constructionism. Cambridge: Harvard University Press.

Gergen, K. J. (2002). The Challenge of Absent Presence. In J. E. Katz \& M. A. Aakhus (Eds.), Perpetual Contact: Mobile Communication, Private Talk, Public Performance (pp. 227241). Cambridge, UK: Cambridge University Press. doi: 10.1017/CBO9780511489471.018.

Gerrig, R.J. (1993). Experiencing Narrative Worlds: On the Psychological Activities of Reading. New Haven: Yale University Press.

Gillings, M. (2000). Plans, elevations and virtual worlds: The development of techniques for the routine construction of hyperreal simulations. In J.A. Barceló, M. Forte, D.H. Sanders (Eds.), Virtual Reality in Archaeology. Oxford: BAR International Series 843.

Gordon, A. (1997). Ghostly Matters: Haunting and the Sociological Imagination. London: University of Minnesota Press.

Goulding, C., Saren, M., \& Pressey, A. (2018). 'Presence' and 'absence' in themed heritage. Annals of Tourism Research, 71, 25-38.

Gregoric, P. (2007). Aristotle on the common sense. Oxford: Oxford University Press.

Hannoum, A. (2005). Paul Ricoeur on Memory. Theory Culture \& Society, 22(6), 123-137.

Hopkins, J. N. (2016). The Genesis of Roman Architecture. New Heaven and London: Yale University Press. 
Hurst, A. (2017). Post-Structuralism. Literary and Critical Theory. doi: 10.1093/obo/9780190221911-0008. Retrieved from https://www.oxfordbibliographies.com/view/document/obo-9780190221911/obo9780190221911-0008.xml\#firstMatch

Husserl, E. (1913). Ideen zu einer reinen Phänomenologie und Phänomenologischen Philosophie (Erstes Buch). The Hague: Niemeyer.

ICOMOS (2008). The ICOMOS Charter for the Interpretation and Presentation of Cultural Heritage Sites. 16th General Assembly of ICOMOS, Québec (Canada). Retrieved February 28, 2020, from https://www.icomos.org/charters/interpretation_e.pdf

Interpret Europe (2017). Engaging citizens with Europe's cultural heritage: How to make best use of the interpretive approach. Witzenhausen: Interpret Europe.

Jaén, S. O., \& Landa, J. A. G. (1996). Narratology: An Introduction. New York: Longman.

Jahn, M. (2005). Narratology: A Guide to the Theory of Narrative. English Department, University of Cologne. Retrieved February 28, 2020, from http://www.unikoeln.de/ ame02/pppn.htm

Jang, S-A., Baik, K., \& Ko. H. (2016). Muru in Wonderland: An Immersive Video Tour with Gameful Character Interaction for Children. In Proceedings of the 2016 ACM Conference Companion Publication on Designing Interactive Systems (DIS '16 Companion). Association for Computing Machinery, New York, NY, USA, pp. 173176.

Kidd, J. (2018). "Immersive" heritage encounters. The Museum Review, 3(1). Retrieved February 28, 2020, from http://articles.themuseumreview.org/tmr_vol3no1_kidd

Lee, Y. S. (2001). Tourist gaze: Universal concept. Tourism Culture E Communication, 3(2), 93-99.

Lehnes, P. (2016). It's philosophy, Tim, but we love the World. In P. Lehnes \& J. Carter (Eds.), Digging Deeper: Exploring the Philosophical Roots of Heritage Interpretation. Retrieved February 28, 2020, from http://www.interpretingheritage.eu/sites/default/files/InHerit_Ebook_1.pdf

Liritzis, I., Al-Otaibi, F.M., Volonakis, P., \& Drivaliari, A. (2015). Digital technologies and trends in cultural heritage. Mediterranean Archaeology and Archaeometry, 15(3), 313332.

MacDonald, W. L. (1986). The Architecture of the Roman Empire II: An Urban Appraisal. New Haven: Yale University Press.

Machidon, O. M., Duguleana, M., \& Carrozzino, M. (2018). Virtual humans in cultural heritage ICT applications: A review. Journal of Cultural Heritage, 33, 249-260.

McAdams, D.P. (1993). The Stories We Live by. New York: The Guilford Press.

Meier, L., Frers, L., \& Sigvardsdotter, E. (2013). The importance of absence in the present: Practices of remembrance and the contestation of absences. Cultural Geographies, 20(4), 423-430.

Merleau-Ponty, M. (1945). Phenomenologie de la perception. Paris: Gallimard.

Perry, S., Katifori, A., Karvounis, M., Economou, M., Young, H., Tost, L. P., \& Roussou, M. (2017). D3.1 - User Requirements \& Scenarios - Alpha. Retrieved February 28, 2020, from https://emotiveproject.eu/wpcontent/uploads/2017/11/EMOTIVE_D3.1_UserReqs-ScenariosA_v1.0.pdf

Pittock, M. (2018). The Scottish Heritage Partnership: Immersive Experiences. Policy Report. University of Glasgow. Retrieved February 28, 2020, from https://www.gla.ac.uk/media/Media_640683_smxx.pdf

Pittock, M. (2019, February 6). Tourist attractions are being transformed by immersive experiences - some lessons from Scotland. The Conversation. Retrieved February 28, 
2020, from http://theconversation.com/tourist-attractions-are-being-transformedby-immersive-experiences-some-lessons-from-scotland-110860

Rahaman, H. (2018). Digital heritage interpretation: A conceptual framework. Digital Creativity, 29, 208-234.

Rahaman, H., \& Tan, B. K. (2009). Interactive space: Searching for a dual physical-virtual world. In T-W. Chang, E. Champion, S-F. Chien \& S-C. Chiou (Eds.), 14th International Conference on Computer-Aided Architecture Design Research in Asia (pp. 669-678). Yunlin, Taiwan.

Ratté, C. (2001). New research on the urban development of Aphrodisias in late antiquity. Journal of Roman Archaeology -Supplementary Series, 45, 116-147.

Rojek, C. (1993). Ways of Escape. Modern Transformations in Leisure and Travel. London: Macmillan.

Rome Reborn (n.d.). About us. Retrieved February 28, 2020, from https://www.romereborn.org/content/aboutcontact

Rose, M., \& Wylie, J. (2006). Animating landscape. Environment and Planning D: Society and Space, 24, 475-479.

Roussou, M., Ripanti, F., \& Servi, K. (2017). Engaging visitors of archaeological sites through "EMOTIVE" storytelling experiences: A pilot at the ancient agora of Athens. Journal of Archeologia E Calcolatori, 28(2), 405-420.

Schwind, V., Knierim, P., Haas, N., \& Henze, N. (2019). Using Presence Questionnaires in Virtual Reality. In Proceedings of the 2019 CHI Conference on Human Factors in Computing Systems (CHI '19). ACM, New York, NY, USA. Retrieved February 28, 2020, from https://doi.org/10.1145/3290605.3300590

Sheller, M., \& Urry, J. (2000). The city and the car. International Journal of Urban and Regional Research, 24, 737-757.

Smith, L. (2012). Discourses of heritage: Implications for archaeological community practice. Nuevo Mundo Mundos Nuevos [En ligne], Questions du temps présent, mis en ligne le 05 Octobre 2012, consulté le 15 Juin 2019. Retrieved February 28, 2020, from http://journals.openedition.org/nuevomundo/64148

Spivak, G. C. (1997). Translator's Preface, Of Grammatology. By Jacques Derrida (pp. ix xxxvi). Baltimore: Johns Hopkins University Press.

Terkenli, T. S. (2002). Landscapes of tourism: Towards a global cultural economy of space? Tourism Geographies, 4(3), 227-254.

Tilden, F. (1957). Interpreting our heritage. Chapel Hill: The University of North Carolina Press.

Todorov, T. (1969). Grammaire du Décaméron. The Hague: Mouton.

Urry, J. (1990). The Tourist Gaze: Leisure and Travel in Contemporary Societies. London: Sage.

Vit-Suzan, I. (2016). Architectural Heritage Revisited: A Holistic Engagement of its Tangible and Intangible Constituents. London: Routledge.

Wheatley, D., \& Gillings, M. (2000). Vision Perception and GIS: Developing Enriched Approaches to the Study of Archaeological Visibility. In G. Lock (Ed.), Beyond the Map: Archaeology and Spatial Technologies (pp.1-27). Amsterdam: IOS Press.

Wright, G. R. H. (1999). Classical landscape with ruins - a Turkish setting. Anatolica, 25, 119.

Young, S. J. (2017). Poleis in Asia Minor: The Observer Through Time (from the 2nd Century B.C. to 3rd Century A.D.). Unpublished doctoral dissertation, University of Melbourne, Melbourne, Australia. 